\title{
U.S. National Debt- A Risk Management Approach
}

\author{
Denise Ginzo, MBA Student \\ d.ginzo.102@westcliff.edu
}

\author{
Simin Hojat, Faculty \\ s.hojat@westcliff.edu
}

\begin{abstract}
The U.S. national debt reached the astounding figure of 22 trillion dollars in 2018 (Gomes \& Sinclair, 2019). It splashed onto the headlines of newspapers and became a topic of interest for Nobel laureate economists, dividing opinions on the potential impacts and the necessity of corrective measures. Krugman (2019) advocates that the national debt is trivial for a large economy like the U.S.; whereas, economists, such as Summers (2019), assume a more cautious position in recommending clear restrictions on the never-ending rise in the national debt. Some intriguing questions persist: should measures to restrain or reduce the debt be taken? If so, what is the ideal time to put them into effect? The purpose of this study is to analyze the reasons for the increasing U.S. national debt and to raise a discussion on the ideas of these reputed economists to address these questions. Additionally, the fundamental principles of risk management have been explained to evaluate the national debt from a different perspective (Homan, 2013). The findings of this research show that there are similarities between the theory of risk management and the risk concerns involved in the U.S. national debt. The social impact of this research includes the potential for the risk management tools identified to be used in analyzing the sovereign national debt.
\end{abstract}




\section{Introduction}

Historically, changes in the U.S. national debt and economic growth have moved in opposite directions, reflecting governmental responses to war situations and economic downturns by means of their fiscal policy (Bell, Johnston, \& Jones, 2015). Whenever an economy weakens, the government adjusts their fiscal policy and increases government expenditures to foster economic activity. On the contrary, when the economy is in the expansionary conditions, the government reduces expenditures and increases taxes, adopting a contractionary fiscal policy (Elmendorf \& Sheiner, 2017). However, there has recently been a disruption in this countercyclical fiscal policy, as in this current fully employed and growing economy, the national debt has begun to persistently increase (Elmendorf \& Sheiner, 2017). Unravelling this peculiar behavior is pivotal in order to understand the contemporary economic scenario, the position of the U.S. in the world economy, and the potential challenges that will be faced in the future.

In the long run, continuous deficits and large government spending can lead to crowding out of private investments, can increase interest rates, reduce growth, and ultimately, boost the national debt (Matthews \& Driver, 2013). As an example, in 2018, the amount of government securities held by domestic private investors hit the startling amount of nearly 6 trillion dollars, which crowded out the money market, attracted by the federal borrowings to support the national debt (National Debt, 2019).

Interestingly though, economists do not gauge the upward trend of national debt as a problem itself as long as its cost remains lower than the rate of growth (Summers \& Furman, 2019). The key issue is that interest rates vary depending on factors that may be out of the government and economists' control, making it impossible to predict when fluctuations will occur (Summers \& Furman, 2019). This uncertain environment is the focus of risk management principles which help institutions to identify major threats and evaluate the best response to the identified risks (Homan, 2013). In this study, the risk management perspective was adopted to complement the analysis of the current U.S. debt and evaluate the adequate risk response, underpinned in the qualitative assessment of the most impactful risks.

\section{Literature Review}

A historical path of the national debt evolution is pivotal to understand its main drivers, focusing on the major swings observed from the Constitution ratification until present day. The forethought of previous behaviors and impacts can support the appraisal of alternatives and decision-making on the necessary measures to tackle the national debt, if and when they happen to be required.

Throughout the American constitutional history, the national debt has been propelled by wars and economic recessions/depressions and has withered in peaceful, prosperous times, as depicted in Figure 1 (Huntley, 2010). Following this pattern, the period of 1791-1868 ended with a national debt of $\$ 2.6$ billion. This was the result of the remnants of the American Revolutionary War and the American Civil War (Catherwood, 2000).

Henceforth, World War I (WWI) added a debt of $\$ 26$ billion, equal to 30\% of gross domestic product (GDP), which measures the economic growth of a country based on consumption, investments, government expenditures, exports and imports (Dao, 2018). In the 1920's, the national debt was largely reduced due to the repayments of the countries involved in WWI, a fully employed economy, and the performance of the stock market and real estate (Davidson, 2010). The great depression of 1932 left a legacy of $40 \%$ debt to GDP (\$34 billion) in 1936, consolidating the role of the federal government and the Federal Reserve Bank (FED) as the safeguard of economic wellbeing (Davidson, 2010). Soon after, World War II (WWII) spurred the national debt to its highest level in history, at $120 \%$ of GDP in 1946 (Davidson, 2010). After WWII, the dollar emerged as the world reserve currency, ensuring 
the U.S. supremacy in international trade and the global financial system. In 1944, the
Brenton Woods agreement established the dollar-gold

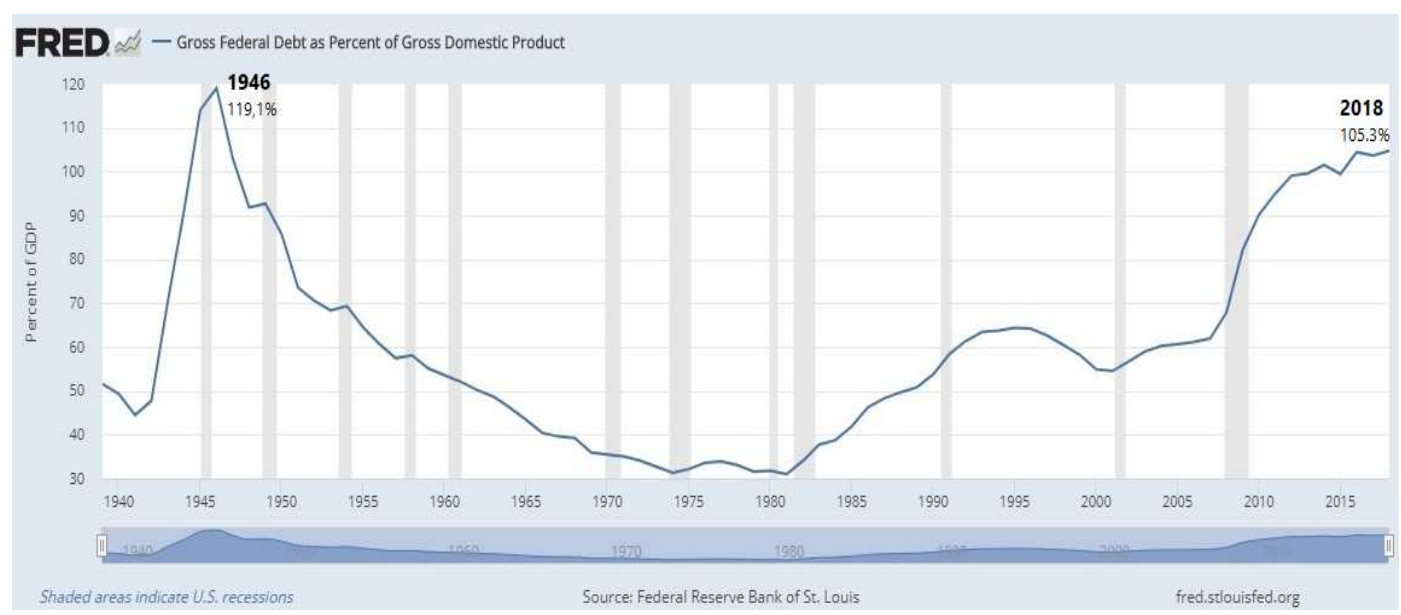

Figure 1. Company's Assets/Liabilities.

Debt as a \% of GDP. Reprinted from FRED Economic Data, by FRED, 2019, retrieved from https://fred.stlouisfed.org/series/GFDGDPA188S

Henceforth, World War I (WWI) added a debt of $\$ 26$ billion, equal to $30 \%$ of gross domestic product (GDP), which measures the economic growth of a country based on consumption, investments, government expenditures, exports and imports (Dao, 2018). In the 1920's, the national debt was largely reduced due to the repayments of the countries involved in WWI, a fully employed economy, and the performance of the stock market and real estate (Davidson, 2010). The great depression of 1932 left a legacy of $40 \%$ debt to GDP (\$34 billion) in 1936, consolidating the role of the federal government and the Federal Reserve Bank (FED) as the safeguard of economic wellbeing (Davidson, 2010). Soon after, World War II (WWII) spurred the national debt to its highest level in history, at $120 \%$ of GDP in 1946 (Davidson, 2010). After WWII, the dollar emerged as the world reserve currency, ensuring the U.S. supremacy in international trade and the global financial system. In 1944, the Brenton Woods agreement established the dollar-gold connection which meant that other countries could buy and trade dollars based on a fixed gold conversion rate (Costigan, Cottle, \& Keys, 2017). U.S. hegemony was strengthened, bringing along capitalistic and free market concepts to international trade that opened new foreign markets to American companies, fostering a strong long-lasting American economic growth that gradually shrank the national debt (Costigan, Cottle, \& Keys, 2017). The "golden" U.S. hegemony endured until 1971 when President Nixon was forced to withdraw the dollar-gold standard because the golden reserves were far below the supply of dollars required to face the ascending national debt. This ascension was due to Korean and Vietnam War expenditures, welfare programs, and liabilities held by European nations, which caused an inflationary effect. Even after the withdrawal, only the U.S. "possessed the necessary political control over financial institutions that would facilitate capital flows", which is the reason the U.S. dollar persisted as the world reserve currency (Costigan, Cottle, \& Keys, 2017, p. 109). Henceforth, the Federal Reserve was able to manage the monetary policy more freely, as the money supply was no longer restricted to the gold correlations imposed by the Brenton Woods agreement (Costigan, Cottle, \& Keys, 2017).

Contemporary Surge and Projection of the National Debt 
During President Ronald Reagan's era (19821989), the national debt entered the $\$ 3$ trillion threshold, reaching the ratio of $50 \%$ to GDP in 1989 ("FRED gross federal debt," 2019). This debt and skyrocketed $103.4 \%$ of GDP ("FRED gross federal debt," 2019).

A forecast of the U.S. national debt predicts that debt held by the public will reach an astounding $144 \%$ of GDP by 2049 , which includes

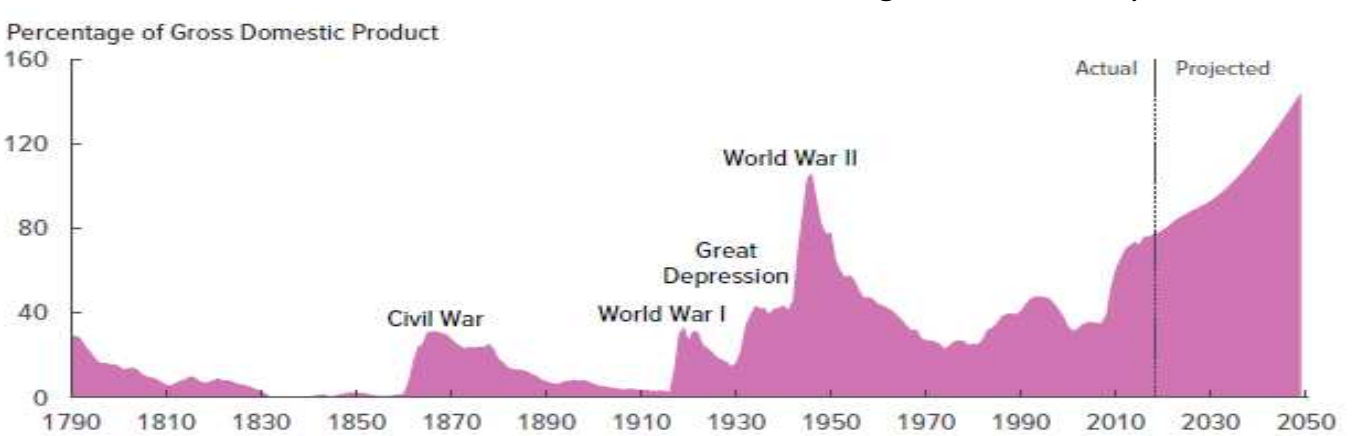

Figure 2. Forecast of Debt Held by the Public.

Reprinted from The 2019 Long-Term Budget Outlook, by CBO, 2019, retrieved from https://www.cbo.gov/system/files/2019-06/55331-LTBO-2.pdf upsurge was derived from the tax cuts that were enforced in an attempt to endure the recession caused by the elevation in interest rates, the increase in social programs and the military expenditures used to confront the Cold War (Gilpin, 1987).

Soon after, the administration of President George W. Bush (2002-2009) accumulated \$6 trillion in debt, shifting the ratio to GDP to $82 \%$ in 2009 ("FRED gross federal debt," 2019). A major contributor to this change was the military spending on the War on Terror that was launched after the September $11^{\text {th }}$ attack, and included the proceeding Afghanistan and Iraq war (Leffler, 2011). Additionally, the Bush administration dealt with the early stages of the subprime crisis. President Barack Obama's mandate between 2010-2017 absorbed the Afghanistan and Iraq wars and the full blow-out of the subprime bubble, which severely undermined the U.S. financial system and economy.

In view of the U.S. financial hegemony, the crisis spread out quickly to global markets in what was named the great recession (Matthews \& Driver, 2013). It took a decade and a massive expansionary fiscal policy to recover the U.S. economy, which accumulated to $\$ 8$ trillion in interest payments on accumulated debt as illustrated in Figure 2 ("The 2019 long-term budget outlook," 2019). Moreover, the U.S. Treasury has issued securities to finance the national debt of nearly $\$ 21.9$ trillion in December 2018, out of which $37 \%$ were owned by FED and governments and 63\% were privately held ("Treasury bulletin," 2019). Foreign investors hold $29 \%$ of treasury securities that are concentrated in China (5.1\%), Japan (4.7\%), Brazil (1.4\%) and the United Kingdom (1.3\%).

\section{Implications}

An ever-raising national debt poses a wide variety of threats to the U.S. economy that could substantially affect the country's growth and the world economy as a whole. The U.S. is the largest economy in the world and, due to the role of U.S. dollar as the world currency, has a special leading position. This study used the enterprise risk management (ERM) principles to evaluate the major threats to the U.S. economy.

The potential impacts of such a roaring national debt are met with divided opinions. Krugman (2018), Nobel Prize economist in 2008, advocates for the fact that the present national debt is "absolutely trivial" when viewed through a Keynesian Model and will not evolve nor spiral as long as the average interest rate on the debt stays below the economic growth plus inflation 
(p. 2). On the contrary, he believes that, as the GDP is higher than the debt service rate (around $2 \%$ for a 10 -year bond), the debt to GDP ratio tends to reduce in the long-term (Krugman, 2019). In his view, the gradual increase in national debt during the 2008 great recession was detrimental to speeding up recovery.

Furthermore, Krugman (2019) argues that even in a full employed economy, the U.S. government should increase its spending to invest in ramping up infrastructure and health and education, as this would provide a potential avenue for long-term pay-off. He asserts that in the recessionary era, the private sectors were not confident in investing in production, even at lower interest rates, due to a risk-averse behavior (Krugman, 2019). In fact, statistics confirm a notable declining tendency in national savings and investments (both, private and public sector), as they have plummeted from $10 \%$ of GDP in 1969 to nearly 4\% of GDP in 2013 (Cole, 2014). The retraction in savings is a matter of concern since savings is one of the determinants of growth that generates investment, according to the Solow growth model (Stein, 2017). Despite his reassuring speech, Krugman (2018) recommends prudence in dealing with debt, "because there may be future contingencies when real interest rates rise and debt becomes an issue," though nobody knows when this could happen (p. 2).

Summers (2019), former chief economist of the World Bank (1991-93), U.S. Treasury secretary (1999-2001) and President emeritus at Harvard University, agrees with the deficit fundamentalists "that the debt cannot be allowed to grow forever" and the budget policy should comply with constraints (p. 1). On the other hand, budgeters should also not obsess against debt, as long as the interest rates on the debt remain low because reckless cuts in government expenditures could harm the U.S. economy even more than the large national debt (Summers \& Furman, 2019). Summers and Furman (2019) argue that a decrease in revenue, rather than augmented expenditures, has propelled deficits and better planning revenues should be a budgetary priority.
Indeed, the economic scenario varies worldwide. During the last 20 years, change was the only certain element in terms of demographics, technology, cultural values, trade, and economics, as noted by Nobel laureate, Spence (2019). The world witnessed the collapse of the Soviet Union, the formation of the European Monetary Union, the establishment of the euro as a common European currency, the rise of the Asian dragons (Japan and South Korea), the growth of emerging countries (especially China and India), the shift of manufacturing centers, the loom of service activities, and the continuous search for attaining competitive advantage (Spence, 2019). All these changes and the recent digital revolution affected economies, business models, supply chain structures and job profiles in such a way that an underperformance in the global economy was expected in the face of the adjustments to this new reality (Spence, 2019).

This global scenario is a challenge to the U.S. and could explain the slow reaction to the great recession. There are still relevant issues to face, such as the fact that baby boomers are retiring and being replaced by fewer workers, which might deplete the social security fund by 2035 , the aging population will increase health expenditures, technological jobs will continue to require investment in education to adapt the labor force, and the deprecated infrastructure will call for the need of investments (Matthews \& Driver, 2013).

These crucial issues justify the maintenance of government expenditures that are focused on their solutions. Additionally, the government should restrict spending in other areas and adopt pay-go budgeting, by only proposing costs assigned to the respective revenues (Summers \& Furman, 2019). Regarding external policy, the main issues involve the expanded role of China in the world economy and financial markets in addition to the inquiry of China, Russia and the organization of the petroleum exporting countries (OPEC) on the maintenance of the dollar as a world reserve currency (Costigan, Cottle, \& Keys, 2017).

Taking all these different views into consideration, we could conclude that new debt 
accumulation is only worthwhile if it is directed towards productive investments.

\section{Perception of Risk}

An accentuated perception of risk related to the U.S. economy and the U.S. institutional capacity to cope with the national debt is pervasive (Homan, 2013). Organization for Economic Co-operation and Development (OECD) debt to GDP rank in 2015, for example, depicted the U.S. as being close to risky leveraged economies, like Portugal, Spain, Greece and Japan ("General government debt," 2019). The risk of American treasuries has augmented, as perceived by Standard \& Poor's Financial Services LLC, a rating company, when it downgraded U.S. bonds from AAA to AA- in 2011, affecting the U.S. and the world economy (Matthews \& Driver, 2013). Investors may feel reluctant to invest in U.S. bonds, unless higher interest rates compensate their risk, which could direct the country towards a fearful debt spiral that could unleash the negative contingencies mentioned by Krugman (2019).

In this sense, Spence (2019) foresees a long period of uncertainty, when "caution may seem like the best policy for companies, investors and even governments," but without freezing investments (para. 13). The lack of investment in new technologies and education can leave countries behind in terms of growth (Spence, 2019). This lagged economic position is observed in growing economies in which capital and labor generates great growth at first, and there is much to be done in terms of infrastructure, factories, and so on. However, after a while, those economies are caught in the middle-income trap and get stuck, because they lack innovation to propel productivity and growth, which requires education, technology and solid institutions, amongst other factors (Glawe \& Wagner, 2016).

\section{Risk Management Approach}

Unsurprisingly, ERM has been largely implemented by companies in the last decades (Homan, 2013). It comprises a set of principles and capabilities to effectively "deal with uncertainty and associated risk and opportunity, enhancing the capacity to build value" and to achieve strategic objectives when considering the risk tolerance thresholds in decision-making, as well as optimizing the use of resources and potential outcomes ("Enterprise risk management," 2014, p. 1). Likewise, these principles can be of great value to federal and state administration in their struggle to deal with the challenges of the globalized, volatile and complex economic environment, albeit observing the specifics of public governance and the magnitude of impacts (Homan, 2013). In any case, the stages of risk identification, risk assessment, risk response and monitoring are essential to support the design of alternatives, structuring of policies, decision-making and involvement of stakeholders (Homan, 2013).

As far as the national debt is concerned, a practical application of ERM principles will possibly address two of the significant risks (SR) previously mentioned by the prominent economists: the potential increase in the debt service rate and the burst of social security and health expenses as a result of the population aging (Matthews \& Driver, 2013). The staggering impact of these two risks on the national debt is an unusual unanimity among economists, as they could ultimately provoke a sovereign crisis.

Fortunately, the probability of SR occurrence in the short run is fairly low, despite their potential catastrophic impacts (Elmendorf \& Sheiner, 2017). The long run scenario is even more challenging due to the massive amount of baby boomers retiring that would dry out social funds and narrow the governmental margin of maneuver (Elmendorf \& Sheiner, 2017). As a consequence of their high impact and low likelihood, SR would be positioned in the yellow area of the risk map presented in Figure 3, which points to a timely proper risk response (Elmendorf \& Sheiner, 2017). Elmendorf and Sheiner (2017) proposed gradual policy adjustments in the next decade, providing time for people and institutions to adapt, such as a reduction in social security and Medicare calculations, an increase in taxes, and a raise in federal investments in specific areas including social benefits and infrastructure modernization. 
Although the debt to GDP should still rise in the next decade, Elmendorf and Sheiner (2017) expect the mitigation of these threats will ultimately create favorable conditions for debt to GDP consistent decline in the long-run. It is worthy of comment that the ERM process aims to reduce the severity of impacts or their likelihood to acceptable levels, yet risks would

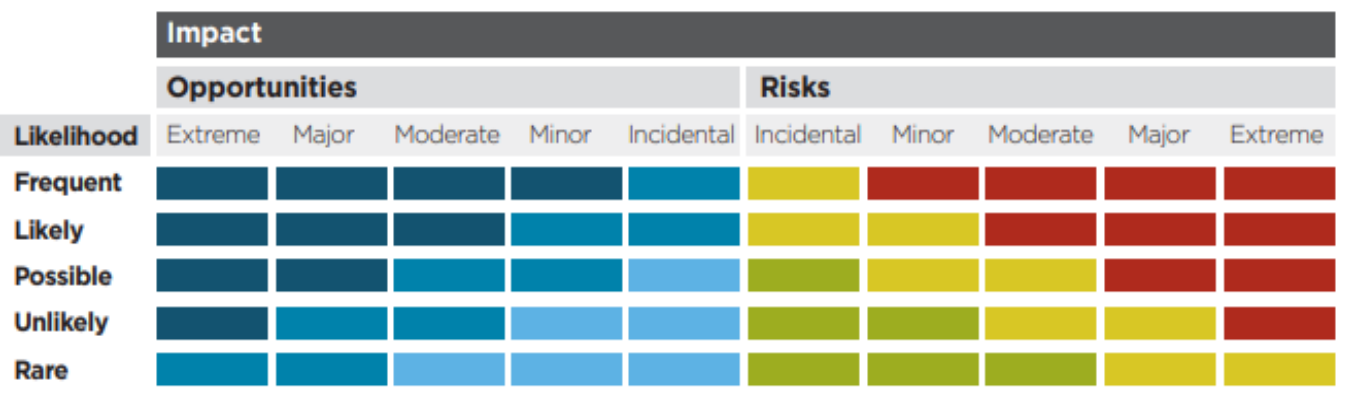

Figure 3. Risk and Opportunity Heat Map.

Reprinted from Coso Documents, by Coso, 2012, retrieved from https://www.coso.org/Documents/COSOERM\%20Risk\%20Assessment\%20in\%20Practice\%20Thought\%20Paper\%200ctober\%202012.pdf

hardly be completely eliminated (Curtis \& Carey, 2012).

\section{Conclusion}

Undoubtedly, analyzing the U.S. national debt is far from trivial, as attested by the several Nobel laureate economists referred to in this article. In the opinion of Krugman (2018), the government should liberally increase their indebtedness and national debt, as long as economic issues are addressed to generate longterm values. Spence (2019) contextualized the world scenario and its relentless changes in demographics, technology, cultural values, trade, and economics as potential causes for the country's economic underperformance. This underperformance is due to the expressive bump these changes have caused to business models, institutions and society. The advice of Summers (2019) is that national debt should be examined in a balanced way, creating thresholds for its rise; nevertheless, this must be done without restraining government and FED maneuvers related to fiscal and monetary policies. Despite the economists' different approaches, it is possible to identify a common view, involving the necessity of government investment in infrastructure, health, education and generation of government revenue, as well as a general concern about situations that could increase economic threats like the debt service interest rate and population aging. The increased perception of risk towards the strength of the U.S. economy to repay such a stunning national debt in the face of an uncertain global scenario is also a meaningful unanimity.

The application of the ERM principles unveiled that the staggering impact of the U.S. sovereign crisis, even though unlikely, would put the American financial hegemony at risk, impairing people's lives and economies worldwide (Matthews \& Driver, 2013). The positioning of SR in the yellow area of the heat map equates to a need for a proper risk response, which theoretically, would answer the question of whether some measure to restrain or reduce the national debt should be taken (Curtis \& Carey, 2012).

The ERM recommendation is aligned to the cautious policy proposed by Spence (2019) and seems to be a wise way to proceed. Nevertheless, regarding the question about the time-frame for the implementation of measures to reduce the national debt, Elmendorf and Sheiner (2017) suggest a medium to long-term subtle risk response, compliant with the cautious policy advice. This response is composed by gradual policy adjustments in the next decade that would provide time for institutional adaptation. 
These conclusions demonstrate that ERM principles could positively contribute to public strategic decision-making and policy development. As suggested by Curtis and Carey (2012), the risk management process should constantly optimize and update to incorporate the changes necessary in a company's business environment, and the same can be applied to sovereign debt. In this sense, it is important to highlight that the risk assessment mentioned in this study is limited to a qualitative analysis of key risk factors. Additional research must be done to further analyze the application of the risk assessment principles in analyzing sovereign debts. 


\section{REFERENCES}

Arghyrou, M., \& Kontonikas, A. (2012). The EMU sovereign-debt crisis: Fundamentals, expectations and contagion. Journal of International Financial Markets, Institutions and Money, 22(4), 658-677. https://doi.org/10.1016/j.intfin.2012.03.003

Bell, A., Johnston, R., \& Jones, K. (2015). Stylised fact or situated messiness? The diverse effects of increasing debt on national economic growth. Journal of Economic Geography, 15(2), 449. doi:10.1093/jeg/lbu005

Catherwood, H. R. (2000). The U.S. national debt. The Government Accountants Journal, 49(2), 66-67. Retrieved from https://co21kf341-mp03-y-https-search-proquestcom.proxy.lirn.net/central/docview/222371648/fulltext/58290C729576414APQ/1?accountid=158986

Cole, A. (2014). Losing the future: The decline of U.S. saving and investment. Tax Foundation Fiscal Act, 439, 1-10. Retrieved from https://files.taxfoundation.org/legacy/docs/TaxFoundation_FF439.pdf

Costigan, T., Cottle, D., \& Keys, A. (2017). The US dollar as the global reserve currency: Implications for US hegemony. World Review of Political Economy, 8(1), 104-122. doi:10.13169/worlrevipoliecon.8.1.0104

Curtis, P., \& Carey, M. (2012). Risk assessment in practice. Retrieved from https://www.coso.org/Documents/COSOERM\%20Risk\%20Assessment\%20in\%20Practice\%20Thought\%20Paper\%200ctober\%202012.pdf

Davidson, P. (2010). Making dollars and sense of the U.S. government debt. Journal of Post Keynesian Economics, 32(4), 661-666. doi:10.2753/PKE0160-3477320410

Dao, M. (2018). Tests of a more comprehensive model of economic growth in lower middle-income countries. Journal of Economic Studies, 45(1), 46-58. https://doi.org/10.1108/JES-12-2016-0257

Elmendorf, D. W., \& Sheiner, L. M. (2017). Federal budget policy with an aging population and persistently low interest rates. The Journal of Economic Perspectives, 31(3), 175-194. http://dx.doi.org/10.1257/jep.31.3.175

Federal Debt (2019). In U.S. Government Accountability Office. Retrieved from https://www.gao.gov/americas_fiscal_future?t=federal_debt

FRED gross federal debt as percent of gross domestic product (2019). In FRED Economic Data. Retrieved from https://fred.stlouisfed.org/series/GFDGDPA188S

Gilpin, R. (1987). American policy in the post-Reagan era. Daedalus, 116(3), 33-67. Retrieved from http://www.jstor.org/stable/20025108

Gomes, J., \& Sinclair, T. M. (Producers) (2019, March, 15). U.S. debt: Is it the calm before the storm? [Audio podcast]. Retrieved from https://knowledge.wharton.upenn.edu/article/u-s-debt-calm-storm/

Glawe, L., \& Wagner, H. (2016). The middle-income trap: Definitions, theories and countries concerned - a literature survey. Comparative Economic Studies, 58(4), 507-538. http://dx.doi.org/10.1057/s41294-0160014-0

Homan, J. E. (2013). ERM for the public sector: A case study. The Journal of Government Financial Management, 62(2), 34-40. Retrieved from https://www.flipsnack.com/FCAA7CF569B/summer-2013-journal-ofgovernment-financial-management.html?pn=5

Huntley, J. (2010, July 27). Federal debt and the risk of a fiscal crisis. In CBO. Retrieved from https://www.cbo.gov/publication/21625

Krugman, P. (2018, September 11). On the debt non-spiral. In The New York Times. Retrieved from https://www.nytimes.com/2018/09/11/opinion/on-the-debt-non-spiral.html

Krugman, P. (2019, January 3). Who's afraid of the budget deficit? In The New York Times. Retrieved from https://www.nytimes.com/2019/01/03/opinion/house-democrats-budget-deficit.html

Leffler, M. (2011). 9/11 in retrospect: George W. Bush's grand strategy, reconsidered. Foreign Affairs, 90(5), 33-44. Retrieved from http://www.jstor.org/stable/23041774

Matthews, W., \& Driver, R. (2013). Managing federal debt: A two phased approach. Journal of Management Policy and Practice, 14(1), 105-111. Retrieved from https://search.proquest.com/docview/1429682269?accountid=158986

Spence, M. (2019, March 25). The economic consequences of global uncertainty. Retrieved from https://www.project-syndicate.org/commentary/global-economic-slowdown-uncertainty-causes-bymichael-spence-2019-03 
Stein, S. H. (2007). A beginner's guide to the Solow Model. The Journal of Economic Education, 38(2), $187-193$. doi:10.3200/JECE.38.2.187-193

Summers, L. H., \& Furman, J. (2019, January 28). Who's afraid of budget deficits? Retrieved from http://larrysummers.com/2019/01/28/whos-afraid-of-budget-deficits/\#more-36860

The 2019 long-term budget outlook. (2019, June). In Congressional Budget Office. Retrieved from https://www.cbo.gov/system/files/2019-06/55331-LTBO-2.pdf Treasury bulletin. (2019, September). In Bureau of the Fiscal Service. Retrieved from https://fiscal.treasury.gov/reports-statements/treasurybulletin/

Westcliff International Journal of Applied Research. Vol. 3, No. 1. Fall 2019 